Jurnal Keperawatan Padjadjaran

ISSN 2338-5324 (print)

ISSN 2442-7276 (online)

Online di http://jkp.fkep.unpad.ac.id

DOI : $10.24198 / \mathrm{jkp}$

\title{
Increasing Prevention Knowledge of Sexual Violence and Emotional Maturity on Children through the Mini-Movie Media
}

\author{
Iqlima Dwi Kurnia*, Ilya Krisnana, Farida Norma Yulianti \\ Faculty of Nursing, Universitas Airlangga, Surabaya, Indonesia \\ Corresponding email:iqlima.dwi.k@fkp.unair.ac.id
}

Submitted: 20-07-2020 Accepted: 18-12-2020 Published: 27-12-2020

\begin{abstract}
Sexual violence against children is one of the world's problem that has an impact on the mental, physical, and psychological conditions such as depression, fear, shame, which can lead to suicide for the victim. The level of prevention knowledge and emotional maturity in the child needs to be grown. Objective of this study was analyze the effect of mini movie on the level of knowledge prevention of sexual violence and the level of emotional maturity in school-age children. Mini movie video according to research by the American Psychological Association (APA) is an audio-visual media with message conveyed in the form of short films through hearing and sight. Mini movie contains 2 video, the first video taken from UNICEF Indonesia. The second video came from center for study and child protection (PKPA). This study used quasi experimental design with two groups and involved 85 students. The Emotional Maturity and Knowledge of Child Abuse Questionnaire used as the instrument. This research conducted used a simple random sampling technique. The research showed that mini movie media had a significant impact on the level of prevention knowledge sexual violence $(p=0.000)$ and the level of emotional maturity $(\mathrm{p}=0.000)$ Mini movie media becomes a mass approach in modern era that can provide accurate information in delivering health messages for children. Education through mini movie media can stimulate children's awareness and teacher as an effort to prevent sexual violence by increasing children's knowledge and emotional maturity.
\end{abstract}

Keywords: Child abuse sexual, knowledge, motion picture. 
Iqlima Dwi Kurnia: Increasing Prevention Knowledge of Sexual Violence and Emotional Maturity

\section{Introduction}

Domestic violence is a common problem in society (Chimeno et al., 2020). Sexual violence is a form of criminal action that is undertaken to satisfy the sexual desire by forcing, persuading, threatening of children powerlessness in the conduct of forced sexual activities (McKibbin et al., 2017). Children problems frequently occur in relation to physical, psychological and social changes (Solehati et al., 2018). The Lack sexual education taught in children can influence the level of emotional maturity and child knowledge in assessing deviant situations in the surrounding environment (Edwards et al., 2019). The advantages of Mini movie media that can be used as a research intervention are displaying animated images that sound can emphasize the reality of the problems that occur, so that the information provided can be understood (Andriani, Ardianto, \& Srisanto, 2017).

Studies conducted internationally confirm that child sexual abuse is a much more widespread problem than previously thought, with even the lowest prevalence rates including a large number of victims that need to be taken into account (Pereda et al., 2009). The analysis showed that 7.9\% of men (7.4\% without outliers) and $19.7 \%$ of women (19.2\% without outliers) had suffered some form of sexual abuse prior to the age of eighteen (Pereda et al., 2009). Reports obtained by the Chairperson of the KPAI regarding sexual violence against boys have increased, seen from data on cases that have occurred in several regions of Indonesia (Setiawan, 2018)

Many victims of acts of violence acts are psychologically traumatized (Franke et al., 2019). There are $95 \%$ of male victims from sexual violence do not report themselves to child protection (McKibbin et al., 2017). Psychosocial problems experienced by child victims of sexual violence also felt by the family (Novianty et al., 2015). The Indonesian Child Protection Commission (Quoted in UNICEF, 2018)states that sexual violence that occurs to children every year is quite high (more than 100 cases) and the perpetrator is the closest person to the victim Perpetrators of sexual violence against children committed by close people such as stepfathers and children, uncles, closest family $(85 \%)$ and the rest (15 percent) by outsiders (PKPA, 2015).

Sexual abuse and sexual assaults against are among the most significant threats to their health and well-being (Runarsdottir et al., 2019). The increasing cases of sexual violence can have a negative impact on victims, such as physical and psychological damage in the form of mental trauma, depression (Wheeler \& McElvaney, 2017). Behaviors of sexual violence in children with physical or emotional abuse can impact the development of sexual behavior and aggression that are harmful to the child's Future (Fong et al., 2017).

The impact of sexual violence occurring in children can affect the level of emotional maturity and knowledge in children in view of future life (Louboutin \& Gardner, 2013). Lack of emotional maturity and lack of knowledge in children can make children victims of sexual violence (Warraitch et al., 2020). A strategy that can be given to increase children's knowledge and emotional maturity is to provide health education using mini-movie media. The advantages of minimovie media that can be used as a research intervention are by displaying animated images that sound can emphasize the reality of the problems that occur (Wahyuningtyas, 2017).

The results of the study stated that the most common identity of the perpetrator was the biological father $(50 \%)$, biological sibling $(14.4 \%)$, stepfather $(13.9 \%)$, and parent's boyfriend $(12 \%) .6 .5 \%$ of the perpetrators were female and 93.5\% were male (Koçtürk \& Yüksel, 2019). Sexual education with the buzz method can increase the role of parents in educating children to prevent sexual abuse. Few children who have reported experiencing sexual violence can give misunderstandings about sexual behavior, for that the correct understanding of the child regarding sexuality is indispensable in the hope that the child can know the importance of protecting their self to avoid sexual abused (Van Der Merwe, 2011). However, studies that explain the effect of mini movie on the level of knowledge prevention of sexual violence and the level of emotional maturity in school- 
Iqlima Dwi Kurnia: Increasing Prevention Knowledge of Sexual Violence and Emotional Maturity

age children do not yet exist. The purpose of this study was to analyze the effect of mini movie on the level of knowledge prevention of sexual violence and the level of emotional maturity in school-age children.

\section{Method}

This research was quasi experiment pre-posttest control group design. The population in this research was a 4th grade child elementary School were 217 students. Primary schools used in the study were both in the treatment and control groups in localized areas, precisely in Sawahan District, Surabaya. Selected two schools that meet the criteria, namely elementary schools that have accreditation $\mathrm{A}$ and schools that have never conducted research on sexual violence against children. One school as a treatment group and one school as a control group. The sampling size of this study was based on the calculation of the sample size using the Krejcie and Morgan formula (Nursalam, 2016). The number of samples were 85 . Sampling in this study using probability sampling with the simple random sampling technique. The study was conducted in April to May 2019, with the criteria of inclusion of children who were in grade 4 and the exclusion criteria of children who were sick or not in place.

The Independent variable was mini movie media while the dependent variables in the study were the knowledge of prevention of sexual violence and the level of emotional maturity in school-age children.

Mini movie video according to research by the American Psychological Association (APA) is an audio-visual media with message conveyed in the form of short films through hearing and sight. Mini movie contains 2 video, the first video taken from UNICEF Indonesia (UNICEF, 2014), with the title "Kisah Si Geni with the link https://www.youtube.com/watch?v=z2ajcgKTY\&feature=youtu.be". This video is 1.58 minutes which contains information for children to prevent and be aware of sexual abuse committed by others, especially adults. The second video came from center for study and child protection (PKPA) with the tittle
"Katakan Tidak" (Komisi perlindungan anak Indonesia, 2015) with the link https://www. youtube.com/watch? $\mathrm{v}=$ FsCGDx2SP9k\&fe ature=youtu.be. It takes 10.37 minutes wich contains information about forms of sexual violence, adults who may be the perpetrators of sexual violence, ways to deal with emotions and those who can be contacted to report incidents of sexual violence on children. All videos can be freely accessed by children through YouTube.

Children Knowledge of Abuse Questionnaire (CKAQ) was used to measure the level of children's knowledge about the prevention of sexual violence adopted from Tutty (Tutty, 1995). The CKAQ questionnaire was translated into Indonesian. The translation was carried out by researchers in consultation with experts in the field of English and then for suitability with Indonesians, validity and reliability were tested. All items of the questionnaire had a good validity scores and the reliability testing had a Cronbach's $\alpha$ score $=0,712$. CKAQ questionnaire consisted of 33 questions with 3 subscales namely; 1) self-responsibility (6 questions), 2) make anticipation of self-protection (6 questions), and 3) understanding of what is wrong and right (21 questions). Knowledge questionnaire consist of multiple choice questions which when answered correctly then score 1 and when wrong score 0 . The number for favorable questions are $3,4,5$, ,6, 7, ,8, 9, 10, 13, 14, 16, 17, 18, 20, 21, 23, $24,26,27,28,29,30,32,33$. The number for unfavorable questions are $1,2,11,12$, $15,19,22,25,27,31,32$. Children's level of knowledge is divided into 2 categories, namely low level of knowledge $($ score $<17$ ) and high level of knowledge (score 17-33).

The children's emotional maturity questionnaire modified by the researcher according to the 3 domains of emotional maturity (Hurlock, 1999). The Questionnaire for emotional maturity was translated into Indonesian. The translation was carried out by researchers in consultation with experts in the field of English and then for suitability with Indonesians, validity and reliability were tested. All items of the questionnaire had a good validity scores and the reliability testing had a Cronbach's $\alpha$ score $=0.699$. Child emotional maturity questionnaire consists 
of 12 questions with 3 subscales, namely 1) children's self-understanding that develops towards independent, 2) Understanding the use of mental crisis functions, and 3) emotional control. Response answers in the form of a Likert scale 1-4 namely strongly agree (4), agree (3), disagree (2) and strongly disagree (1) for favorable questions. While questions that are unfavorable are given a reverse score. The number for favorable questions are $1,2.6,9,10,11,12$, while the number for unfavorable questions are $3,4,5,7,8$. The level of emotional maturity is divided into 3 namely 1 ) high emotional maturity (score 37-48), 2) moderate emotional maturity (score 25-36), and 3) low emotional maturity (score 12-24).

The first step researchers went to elementary school to looking for information from one of the principals and teachers. Researchers conducted observations and interviews about research previously that had been done in each school. The researcher also conducted a survey in each class to find the number of data and determine respondents according to the inclusion criteria: 4th grade has 3 classrooms, namely $4 \mathrm{~A}, 4 \mathrm{~B}$, and $4 \mathrm{C}$. Each class consists of 35-36 students who fit the inclusion criteria. The researcher chooses respondents using a simple random sampling technique using paper that was written in the student's presence list number and taken at random, after that the researcher takes the paper according to the large number of samples calculated to be the subject of the study. After obtained the Principal's approval and gave permission to conduct the research. Subject selected according to inclusion criteria. Subject got the research explanation before joined in the study. Informed consent was given to the homeroom teacher the day before the study. The next day the students were given a pre-test before the mini movie intervention.

Mini movie intervention was given twice aweek for two weeks. The subject were given mini movie in the classroom. The total time needed at the first meeting was 30 minutes consist of viewing of Mini movie and the ends with a discussion session. The first mini movie "Si Geni" which contains information for children to prevent and be aware of sexual abuse committed by others, especially adults. While the second meeting was played mini movie from PKPA wich contains information about forms of sexual violence, adults who may be the perpetrators of sexual violence, ways to deal with emotions and those who can be contacted to report incidents of sexual violence on children. So it will be preventing sexual violence behavior. The second meeting was held the day after the first meeting. The next stage the subject was given a posttest questionnaire in one room in school hall at 7 days after intervention for knowledge and 14 days for intervention for emotional maturity. The subject was given the opportunity for 7 days and 14 days to internalize information already obtained through mini movie media in the form of an understanding of knowledge and emotional maturity in the prevention of violent behavior.

The Data was analyzed by using Wilcoxon signed rank test and the Mann-Whitney U Test with the level of significance $\alpha=.05$.

This research has been declared a review and obtained a certificate of Ethical Approval with No. 1370-KEPK issued by the Medical Research Ethics Committee of Faculty of Nursing Universitas Airlangga on April 23, 2019.

\section{Results}

Table 1 Respondent Characteristic (April-May 2019)

\begin{tabular}{|c|c|c|c|c|c|c|c|}
\hline & \multirow{2}{*}{$\begin{array}{c}\text { Characteristic } \\
\text { Category }\end{array}$} & \multicolumn{2}{|c|}{ Intervention group } & \multicolumn{2}{|c|}{ Control group } & \multirow{2}{*}{ total } & \multirow{2}{*}{$\%$} \\
\hline & & $\mathbf{f}$ & $\%$ & $\mathbf{f}$ & $\%$ & & \\
\hline \multirow[t]{5}{*}{ Age } & 9 years & 4 & 9.5 & 0 & 0 & 4 & 4.7 \\
\hline & 10 years & 32 & 76.2 & 34 & 79.0 & 66 & 77.6 \\
\hline & 11 years & 4 & 9.5 & 9 & 21.0 & 13 & 15.2 \\
\hline & 12 years & 2 & 4.8 & 0 & 0 & 2 & 2.5 \\
\hline & Total & 42 & 100.0 & 43 & 100.0 & 85 & 100.0 \\
\hline
\end{tabular}


Iqlima Dwi Kurnia: Increasing Prevention Knowledge of Sexual Violence and Emotional Maturity

\begin{tabular}{llllllll}
\hline Gender & Female & 25 & 59.5 & 17 & 39.5 & 43 & 50.6 \\
& Male & 17 & 40.5 & 26 & 60.5 & 42 & 49.4 \\
& Total & 42 & 100.0 & 43 & 100.0 & 85 & 100.0 \\
\hline
\end{tabular}

Table 2 Knowledge Before and After Intervention Mini Movie (Intervention and Control Group)

\begin{tabular}{|c|c|c|c|c|c|c|c|c|}
\hline \multirow{3}{*}{ Knowledge } & \multicolumn{4}{|c|}{ Intervention group } & \multicolumn{4}{|c|}{ Control group } \\
\hline & \multicolumn{2}{|c|}{ Pre-test } & \multicolumn{2}{|c|}{ Post-test } & \multicolumn{2}{|c|}{ Pre-test } & \multicolumn{2}{|c|}{ Post-test } \\
\hline & $\mathbf{f}$ & $\%$ & $\mathbf{f}$ & $\%$ & f & $\%$ & f & $\%$ \\
\hline Low & 5 & 11.9 & 0 & 0 & 5 & 11.63 & 6 & 14 \\
\hline High & 37 & 88.1 & 42 & 100 & 38 & 88.37 & 37 & 86 \\
\hline Total & 42 & 100 & 42 & 100 & 43 & 100 & 43 & 100 \\
\hline
\end{tabular}

Table 3 The Effect of Mini Movie on Respondent Knowledge (Intervention and Control Group)

\begin{tabular}{lcccc}
\hline \multirow{2}{*}{ Knowledge } & \multicolumn{2}{c}{ Post test Intervention group } & \multicolumn{2}{c}{ Post test Controol group } \\
\cline { 2 - 5 } & $\mathbf{f}$ & $\mathbf{\%}$ & $\mathbf{f}$ & $\mathbf{\%}$ \\
\hline Low & 0 & 0 & 6 & 14 \\
High & 42 & 100 & 37 & 86 \\
Total & 42 & 100 & 43 & 100 \\
\hline
\end{tabular}

Mann Whitney Test $p=0.000$

Tabel 4 Emotional Maturity Before and After Intervention (Intervention and Control Group)

\begin{tabular}{lcccccc}
\hline \multirow{2}{*}{ Emotional Maturity } & \multicolumn{3}{c}{ Intervention group } & \multicolumn{2}{c}{ Control group } \\
\cline { 2 - 7 } & \multicolumn{2}{c}{ Pre-test } & Post-test & Pre-test & Post-test \\
\cline { 2 - 7 } & $\mathbf{f}$ & 0 & $\mathbf{f}$ & $\mathbf{\%}$ & $\mathbf{f}$ & \% \\
\hline Low & 0 & 0 & 0 & 0 & 0 & 0 \\
Moderate & 21 & 50 & 4 & 9.5 & 14 & 13 \\
High & 21 & 50 & 38 & 90.5 & 29 & 30 \\
Total & 42 & 100 & 42 & 100 & 43 & 43 \\
\hline \multicolumn{2}{c}{ Wilcoxon Rank Test $\mathrm{p}=0.000$} & & & Wilcoxon Rank Test $\mathrm{p}=0.317$
\end{tabular}

Table 5 Effect of Mini Movie Media on The Level of Emotional Maturity

\begin{tabular}{lcccc}
\hline \multirow{2}{*}{ Emotional Maturity } & \multicolumn{2}{c}{ Post test Intervention group } & \multicolumn{2}{c}{ Post test Control group } \\
\cline { 2 - 5 } & $\mathbf{f}$ & $\mathbf{\%}$ & $\mathbf{f}$ & $\mathbf{\%}$ \\
\hline Rendah & 0 & 0 & 0 & 0 \\
Low & 4 & 9.5 & 13 & 30.2 \\
Moderate & 38 & 90.5 & 30 & 69.8 \\
Total & 42 & 100 & 43 & 100 \\
\hline
\end{tabular}


Iqlima Dwi Kurnia: Increasing Prevention Knowledge of Sexual Violence and Emotional Maturity

From the table 1 show that the distribution of respondent based of age in the intervention and control grup are mostly 10 years old. The distribution of the gender from each group was mostly girls as many as 25 respondents for intervention group and 26 respondents for control group.

Table 2 show that the level of knowledge of children in the intervention group before giving Minimovie media some respondents have a high level of knowledge category as many as 37 respondents $(88.1 \%)$ and after giving Mini movie media the level of knowledge of sexual violence prevention, experienced a change to the high category as many as 42 respondents $(100 \%)$. The statistical test with the Wilcoxon Rank Test obtained $\mathrm{p}$ value $=0.025(\mathrm{p}<0.05)$. In means that mini movie effect on increasing respondent knowledge. The control group $\mathrm{p}$ value $=0.458$ so that $p>0.05$, which means that there is no significant difference in knowledge between the pre-test and post-test scores.

The statistical test with the Mann-Whitney $\mathrm{U}$ Test obtained $\mathrm{p}$ value $=0.000(\mathrm{p}<0.05)$, indicating that there was a significant effect of Mini movie media on the level of knowledge of sexual violence prevention between students in the intervention group and the control group.

Table 4 show that the level of emotional maturity of children in the intervention group before giving Mini movie media some respondents have the same level category as many as 21 respondents $(50 \%)$ and after giving a change to the high category as many as 42 respondents $(100 \%)$. The statistical test with the Wilcoxon Rank Test obtained $\mathrm{p}$ value $=0.000(p<0.05)$. In means that mini movie effect on increasing emotional maturity. The control group $\mathrm{p}$ value $=0.317$ so that $\mathrm{p}>$ 0.05 , which means that there is no significant difference in emotional maturity between the pre-test and post-test scores.

The statistical test with the Mann-Whitney $\mathrm{U}$ Test obtained $\mathrm{p}$ value $=0.000(\mathrm{p}<0.05)$, indicating that there was a significant effect of Mini movie media on the level emotional maturity between students in the intervention group and the control group.

\section{Discussion}

Provision of information through mini-movie media, can be a strong stimulus to increase knowledge and provide changes in attitudes to respondents. This is in line with research that discusses the effect of a communication is a change in attitude and will depend on the extent to which communication can be considered, understood, and accepted (Azwar, 2015). Knowledge of sexual violence prevention obtained through mini-movie media in health promotion can provide information for respondents and become the most important domain for the formation of behavior and self-awareness in the surrounding environment in an effort to prevent sexual violence.

The Mini movie media had an influence on the increased knowledge of sexual violence prevention. The message that has been delivered in short film through hearing and vision will have more appeal, so the stimulus will give good knowledge to raise the child's behavior and learn other sources. Individuals who have received further stimulus will give knowledge of consciousness in him, so that with the knowledge of prevention of sexual violence the child has the awareness of the dangers and impacts of the crime of sexual violence happening around the environment. A person's good behavior, and an unqualified impression can have a bad impact (Handayani, 2017). The results of this study are consistent with the research conducted by (Van Der Merwe, 2011), which states that media mini movie according to research the American Psychological Association (APA) Audio visual media in quality learning affects a person's good behavior, and an unqualified impression can have a bad impact.

The health promotion model theory aims to provide an intervention in promoting a healthy lifestyle in changing behaviors. (Vives-Cases et al., 2019). The importance of the precautionary knowledge of sexual violence given to children to prevent sexual violence (Tutty, 1995). Child awareness of the dangers of sexual violence gained through a video served on a computer to enhance knowledge with good behavioral changes and not to In overcoming Life's challenges (Davies et al., 2013). 
Iqlima Dwi Kurnia: Increasing Prevention Knowledge of Sexual Violence and Emotional Maturity

The mini movie media has an influence on increasing the children's emotional maturity in an effort to prevent sexual violence. Mini movie is an image and sound that is displayed with an electronic mechanized motion, thus reviving the state of the Illusion of movement (Handayani, 2017).

The effect of awarding mini movie as a method used in animated learning activities can stimulate and attract individual attention, so it can influence the mindset in motivating learning (Abaraogu et al., 2019). Research that has been done according to Edgar Dale cone of learning diagram emphasizes the importance of media for children in education, i.e. information obtained through hearing media and vision can largely be remembered (Reuter et al., 2019). So it will make easier for children to accept the information provided and then knowledge about prevention of sexual violence will increase (Asfar, 2018).

Research has been conducted discussing the existence of most influences on the utilization of electronic mass media audio visuals that influence the character formation of students more critically in addressing and targeting problems occurring in Environment (Van Der Merwe, 2011). The school-based sexual abuse prevention program was shown to be acceptable, feasible and efficacious in improving sexualabuse preventionknowledge and skills of female children. (Warraitch et al., 2020). Heightened reactivity to emotions paired with an immature emotional regulatory capacity and susceptibility to peer influence have all been cited as causing adolescent behavior problems (Madrid et al., 2020) . It seems that integrating emotion regulation skills training with educational components might bring about more effective prevention of sexual abuse In a study of college students, Walsh and colleagues found that those with poor emotional regulation, (meaning they have difficulty acknowledging and accepting emotional states), may also have difficulty recognizing feelings of discomfort, fear, or distress. Because of this, it is likely that they miss out on an internal signal that there is a need to escape a risk situation (Madrid et al., 2020).

The maturity of good emotions is the ability and capacity of individuals to respond and control emotions well critically to solve the challenges of life (Permatasari, 2017). The results of the post-test group treatment showed that most respondents had a high level of emotional maturity. This is also in line with the results of research discussing the prevention of sexual violence through an overview of children's understanding shows that boys are easier to understand sexual education than girls (Permatasari, E., 2017). Girls have an easy nature feel uncomfortable if others have trouble, so that can be used as a profit for the perpetrators of violence to deceive the child in doing the action.

Based on the changes in the level of the emotional maturity of the child's greatest emotion is the understanding of the mental crisis in the treatment group, experiencing the highest increase compared to other emotions maturity characteristics. The use of mental crisis functions in individuals is said to be good when individuals have an objective thinking in understanding the condition of the circled state, and before revealing the emotions in themselves (Moshahid, 2017). This affects the child to be able to use his mental crisis function, which is to think in a sense and understand his perceived feelings in him when confronting the situation in real life. The mini movie discussing how to control emotions in an effort to prevent sexual violence provides an adaptive response to the increase in child emotion maturity on the guilt of behavior of sexual violence occurring around (Tangney, 2004).

\section{Conclusion}

Mini movie media becomes a mass approach in modern era that can provide accurate information in delivering health messages for children. Education using mini movie media can improve children's self-control so as to prevent sexual violence behavior on children. Teachers at school and parents at home can use interesting and easily accessible media to increase children's knowledge about preventing sexual violence.

Would like to express my gratitude with a genuine heart to all respondents and parents/ guardians who have been willing to take the time to participate in this research. 
Iqlima Dwi Kurnia: Increasing Prevention Knowledge of Sexual Violence and Emotional Maturity

\section{References}

Abaraogu, U. O., Onah, U., Abaraogu, O. D., Fawole, H. O., Kalu, M. E., \& Seenan, C. A. (2019). Knowledge, attitudes, and the practice of health promotion among physiotherapists in Nigeria. Physiotherapy Canada, 71(1), 92-100. https://doi.org/10.3138/ptc.2017-79. gh

Andriani, S., Ardianto, D. T., \& Srisanto, E. (2017). Perancangan animasi $2 d$ sebagai antisipasi kekerasan seksual pada anak usia 10 - 12 Tahun. (2d Animation Design as Anticipation of Sexual Violence in Children Age 10 - 12 Years). Jurnal Desain Komunikasi Visual Adiwarna.

Asfar, A. (2018). Pengaruh Penyuluhan Kesehatan Terhadap Tingkat Pengetahuan dan Sikap Tentang Kesehatan Reproduksi di SMP Baznas Provinsi Sulawesi Selatan. (The Effect of Health Counseling on Knowledge Levels and Attitudes About Reproductive Health at Baznas Junior High School, South Sulawesi Province). Journal of Islamic Nursing., June, 0-1. https://doi.org/10.1016/j. chiabu.2017.06.006

Azwar, S. (2015). Sikap Manusia: Teori dan Pengukurannya. (Human Attitude: Theory and Its Measurement). Pustaka Pelajar. Elsevier Inc. https://doi.org/https://doi. org/10.1016/j.sxmr.2017.12.002

Chimeno, S. G., Fernández, J. D., Sánchez, S. M., Ramón, P. P., Ospina, Ó. M. S., Muñoz, M. V., \& Hernández, A. G. (2020). Domestic Violence Prevention System (pp. 10-14). https://doi.org/10.1007/978-3-030-0052453

Davies, P. L., Segalowitz, S. J., \& William, J. (2013). Developmental Neuropsychology Development of Response- Monitoring ERPs in 7- to 25- Year-Olds. 5641(November), 37-41. https://doi.org/10.1207/ s $15326942 \mathrm{dn} 2503$

Edwards, K. M., Banyard, V. L., Sessarego, S. N., Waterman, E. A., Mitchell, K. J., \& Chang, H. (2019). Evaluation of a BystanderFocused Interpersonal Violence Prevention
Program with High School Students. Prevention Science, 20(4), 488-498. https:// doi.org/10.1007/s11121-019-01000-w

Fong, H., Bennett, C. E., Mondestin, V., Scribano, P. V., Mollen, C., \& Wood, J. N. (2017). The Impact of Child Sexual Abuse Discovery on Caregivers and Families: A Qualitative Study. Journal of Interpersonal Violence https://doi. org/10.1177/0886260517714437

Franke, S., Kalweit, C., Frey, A., Heddergott, H., Mitschke, A.-C., Wehrmeyer, M., Heinrichs, N., \& Kröger, C. (2019). [Victims of Acts of Violence during the Procedure of the Victim Reparation Law - Characteristics of the Affected, Acts, Perpetrators and Predictors for the Period Until Claim of Help Provided by Law]. Psychotherapie, Psychosomatik, Medizinische Psychologie, 69(3-04), 105113. https://doi.org/10.1055/a-0601-6701

Handayani, L. (2017). Pengaruh Pendidikan Kesehatan Dengan Media Video Terhadap Tingkat Pengetahuan Tentang Pencegahan HIV/AIDS di SMA Negeri 1 Parigi Kabupaten Pangandaran. unisayogya. (The Effect of Health Education with Video Media on the Level of Knowledge about HIV/AIDS Prevention in SMA Negeri 1 Parigi, Pangandaran Regency). Journal of Nursing, 2. https://doi.org/10.1016/j. childyouth.2018.03.040

Hurlock, E. B. (1999). Psikologi Perkembangan: Suatu Pendekatan Sepanjang Ruang kehidupan (5th ed.). (Developmental Psychology: An Approach Throughout Life's Space (5th ed.)). Erlangga.

Koçtürk, N., \& Yüksel, F. (2019). Characteristics of victims and perpetrators of intrafamilial sexual abuse. Child Abuse \& Neglect, 96, 104122. https://doi. org/10.1016/j.chiabu.2019.104122

Komisi perlindungan anak Indonesia. (2015). Video Katakan Tidak. Retrieved March 20, 2020, from https://www.youtube.com/watch $? \mathrm{v}=$ FsCGD 2 SP9k $\&$ feature $=$ youtu.be.

Louboutin, J.-P., \& Gardner, M. (2013). 
Iqlima Dwi Kurnia: Increasing Prevention Knowledge of Sexual Violence and Emotional Maturity

Decision-making in adolescents: Neuroanatomical basis and consequences for cognitive competence and risk-taking behaviors. In P. Braschi (Ed.), Psychology of Judgment (pp. 1-46). Nova Science Publishers, Inc.

Madrid, B. J., Lopez, G. D., Dans, L. F., Fry, D. A., Duka-Pante, F. G. H., \& Muyot, A. T. (2020). Safe schools for teens: preventing sexual abuse of urban poor teens, proof-ofconcept study - Improving teachers' and students' knowledge, skills and attitudes. Heliyon, 6(6). https://doi.org/10.1016/j. heliyon.2020.e04080

McKibbin, G., Humphreys, C., \& Hamilton, B. (2017). "Talking about child sexual abuse would have helped me": Young people who sexually abused reflect on preventing harmful sexual behavior. Elsavier Child Abuse and Neglect, 70(June), 210-221. https://doi. org/10.1016/j.chiabu.2017.06.017

Moshahid, M. (2017). Emotional maturity and academic achievement of B.Ed students : A co-relational study. International Journal of Advanced Research and Development, 2(3), 133-136.

Novianty, L., Suryani, S., \& Sriati, A. (2015). Analisis Dukungan psikososial yang dibutuhkan keluarga dengan anak yang mengalami kekerasan seksual. (Analysis of Psychosocial Support Needed by Families with Children who experience Sexual Violence). Jurnal Keperawatan Padjadjaran, 3(3). https://doi.org/10.24198/jkp.v3i3.115

Nursalam, S. (2013). Metodologi penelitian ilmu keperawatan pendekatan praktis. (Nursing Research Methodology Practical Approach). Salemba Medika.

Pereda, N., Guilera, G., Forns, M., \& Gómez-Benito, J. (2009). The prevalence of child sexual abuse in community and student samples: A meta-analysis. Clinical Psychology Review, 29(4), 328-338. https:// doi.org/10.1016/j.cpr.2009.02.007

Permatasari, E., S. G. A. (2017). Gambaran Pemahaman Anak Usia Sekolah Dasar
Tentang pendidikan seksual dalam upaya Pencegahan kekerasan seksual pada anak. (Overview of Elementary School age children's understanding of zexual education in efforts to prevent sexual violence in Children). The Indonesian Journal of Health Science, 9(1).

PKPA. (2015). Katakan tidak. (say No). Retrieved March 20, 2020, from https:// docplayer.info/62121971-Ringkasanlaporan-tahunan-pusat-kajian-danperlindungan-anak-pkpa.html

Reuter, K., MacLennan, A., Le, N., Unger, J. B., Kaiser, E. M., \& Angyan, P. (2019). A Software tool aimed at automating the generation, distribution, and assessment of social media messages for health promotion and education research. JMIR Public Health and Surveillance, 5(2), e11263. https://doi. org/10.2196/11263

Runarsdottir, E., Smith, E., \& Arnarsson, A. (2019). The effects of gender and family wealth on sexual abuse of adolescents. International Journal of Environmental Research and Public Health, 16(10), 1788. https://doi.org/10.3390/ijerph16101788.

Setiawan, D. (2018). KPAI: Kekerasan seksual anak laki-laki meningkat. (KPAI: Boys Sexual Violence Rises). Retrieved March 20, 2020, from https://www.kpai. go.id/berita/kpai-kekerasan-seksual-anaklaki-laki-meningkat

Solehati, T., Rahmat, A., Kosasih, C. E., \& Hidayati, N. O. (2018). Relationship between ge, gender and peer group with reproductive healthy behaviour of teen. Jurnal Keperawatan Padjadjaran, 6(2). https://doi.org/10.24198/jkp.v6i2.643

Tangney, J. P. et al. (2004). High Self-Control Predicts Good Adjustment, Less Pathology, Better Grades, and Interpersonal Success. Journal of Personality, October. https://doi. org/10.1016/j.wsif.2018.04.004

Tutty, L. M. (1995). The revised Children's Knowledge of Abuse Questionnaire: Development of a Measure of Children's 
Iqlima Dwi Kurnia: Increasing Prevention Knowledge of Sexual Violence and Emotional Maturity

Understanding of Sexual Abuse Prevention Concepts. Journal Consulting and Clinical Psychological, 19.

UNICEF. (2014). Video Kisah Si Geni. (Geni's Story Video). Retrieved March 20, 2020, from https://www.youtube.com/ watch?v=z2ajcg-KTY\&feature=youtu.be

UNICEF. (2018). Mengakhiri Kekerasan terhadap Perempuan dan Anak di Indonesia. (Ending Violence against Women and Children in Indonesia). Retrieved from March 3, 2020, from https://www.kemenpppa.go.id/ lib/uploads/list/71ad6-buku-ktpa-menegpp-2017.pdf

Van Der Merwe, P. (2011). A school-based socio-emotional programme as strategy against crime and violence. Tydskrif Vir Geesteswetenskappe, 51(3), 388-402.

Vives-Cases, C., Davo-Blanes, M. C., FerrerCascales, R., Sanz-Barbero, B., AlbaladejoBlázquez, N., Sánchez-San Segundo, M., Lillo-Crespo, M., Bowes, N., Neves, S., Mocanu, V., Carausu, E. M., Pyżalski, J., Forjaz, M. J., Chmura-Rutkowska, I., Vieira, C. P., \& Corradi, C. (2019). Lights4Violence: a quasi-experimental educational intervention in six European countries to promote positive relationships among adolescents. BMC Public Health, 19(389). https://doi.org/10.1186/ s12889-019-6726-0

Wahyuningtyas, P. (2017). Pengaruh Pemanfaatan Media Massa Elektronik Audiovisual Terhadap Karakter Peserta Didik Kelas IV Mi Al-Jihad Karanggebang Jetis Ponorogo Tahun Pelajaran. ( The Influence of the Use of Audiovisual Electronic Mass Media on the Characters of Class IV Students of Mi Al-Jihad Karanggebang Jetis Ponorogo Academic Year). Jurnal Kependidikan Dan Kemasyarakatan, 1-107.

Warraitch, A., Amin, R., \& Rashid, A. (2020). Evaluation of a school-based sexual abuse prevention program for female children with intellectual disabilities in rural Pakistan- a feasibility study. Applied Nursing Research, 151391. https://doi.org/10.1016/j. apnr.2020.151391

Wheeler, A. J., \& McElvaney, R. (2017). "Why would you want to do that work?" The positive impact on therapists of working with child victims of sexual abuse in Ireland: a thematic analysis. Counselling Psychology Quarterly, 1-15. https://doi.org/10.1080/095 15070.2017 .1336077 